\title{
Marketing Management for Consumer Products in the Era of the Internet of Things
}

\author{
Reinhold Decker, Christian Stummer \\ Department of Business Administration and Economics, Bielefeld University, Bielefeld, Germany \\ Email: rdecker@uni-bielefeld.de,christian.stummer@uni-bielefeld.de
}

How to cite this paper: Decker, R. and Stummer, C. (2017) Marketing Management for Consumer Products in the Era of the Internet of Things. Advances in Internet of Things, 7, 47-70. https://doi.org/10.4236/ait.2017.73004

Received: May 22, 2017

Accepted: June 30, 2017

Published: July 3, 2017

Copyright $\odot 2017$ by authors and Scientific Research Publishing Inc. This work is licensed under the Creative Commons Attribution-NonCommercial International License (CC BY-NC 4.0).

http://creativecommons.org/licenses/by-nc/4.0/ (c) (i) (8) Open Access

\begin{abstract}
In the Internet of Things (IoT) consumer products like coffee machines and smoke detectors are connected with the Internet, which effectively expands the Internet to the physical world. Such products have the ability to collect and share data from the user's environment and, thus, their broad emergence will affect well-established concepts presented in the extant marketing literature. In order to provide a distinct contribution, we focus on customer relationship management, product life cycle management, as well as business model development and discuss implications of the enhanced capabilities of IoT products in these fields. By means of an extensive analysis of current developments in theory and practice, we systematically deduce ten research propositions. The paper concludes with a synthesis of findings and an outlook to promising directions for further research in IoT-oriented marketing management.
\end{abstract}

\section{Keywords}

Internet of Things, Smart Products, Marketing Management, Product Analytics

\section{Introduction}

In the recent past, a growing number of newly introduced products have been able to sense their environment and share data with users, other products, and/ or companies via the Internet of Things (IoT). Popular examples are Oral-B's Connected Toothbrush, Babolat's tennis racket Play, and Nike's running shoe Nike+ Training. All these products have in common that they extend the basic functionalities of regular products by (additionally) providing the ability to collect and share data via the Internet [1] [2]. We call this new category of data collecting and sharing products IoT-ready products (IoT products, for short).

Such IoT products may be seen as an interim stage in the development of 
smart products, which are able to analyze and, potentially, "interpret" usage data in a goal-oriented way. Smart products thus can make decisions that otherwise would require human cognition. With machine learning methods, for instance, smart products can analyze product usage data in order to learn and adapt to customer preferences over time. Depending on the product type and application purpose, decisions made by a smart product can be used to provide users and the company with recommendations (instead of "just" information as in the case of an IoT product) or to even enable autonomous actuation [3]. As an example, an IoT-ready thermostat, on the one hand, would be able to collect usage data and to provide customers remote access to the heating control via a mobile app. A smart thermostat, on the other hand, operates autonomously and mainly unattended. Smart products regularly use machine learning techniques to analyze customer preferences in the early training stage when customers start using it. Based on a customer's previous product usage behavior, the smart thermostat, to come back to our example, continuously adjusts the room temperature to the thermostat's own predictions about the customer's current preferences. Figure 1 visualizes the development stages from traditional products to IoT products to smart products.

Although many products today are marketed with the label "smart", the current stage of development in the majority of industries is arguably the IoT stage with a focus on connecting products. Popular fields of application for IoT products exist, for instance, in healthcare, home automation, retailing, and transportation. In a few industries, the current stage of development is already moving toward smart products, such as self-driving cars in the automobile industry. Still, IoT products constitute a comparatively new phenomenon. They are of particular interest for marketing theory, because their novel functionalities may change the view to and adequacy of well-established marketing concepts. Thus, the main contribution of this paper lies in the identification and discussion of potential paradigm changes in selected fields of marketing management for consumer products and in the development and motivation of research propositions for advancing marketing theory toward the IoT era. It is thus in line with some other recent works on related topics [4] [5].

The remainder of this paper is organized as follows: In the second section, we

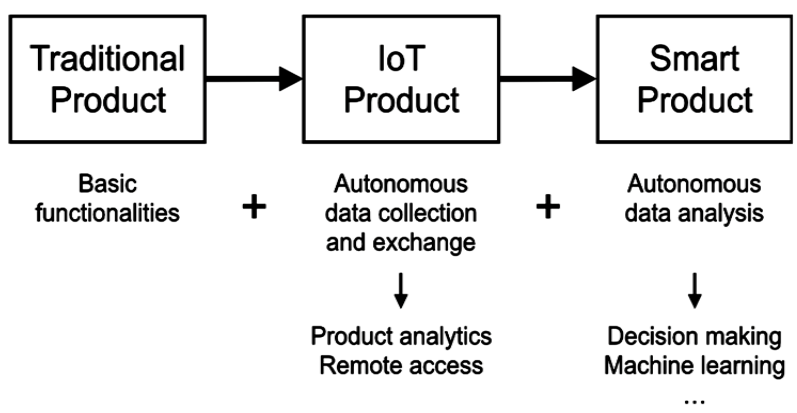

Figure 1. Development stages from traditional products to IoT products and smart products. 
briefly review the existing economic literature on the Internet of Things. In the third section, we then discuss new IoT phenomena and their potential impact on marketing theories from the fields of customer relationship management, product life cycle management, and business model development. We conclude the paper with research implications and an outlook to promising directions for further research.

\section{The Internet of Things in Marketing Management}

The academic literature on IoT-related topics can be traced back to early publications on ubiquitous computing that correspond to the idea of information technologies penetrating "the fabric of everyday life until they are indistinguishable from it" [6]. Since the early work at the Auto-ID Center at the Massachusetts Institute of Technology, the technical discussion on the Internet of Things has gained momentum in various directions, including ambient intelligence [7] [8], human-computer interaction [9], and smart cities [10]. The development of the Internet of Things is accompanied by a stream of technical literature on wireless sensor networks [11] [12] [13] [14] and closely related fields such as sensor technologies [15], wireless communication [16], layered architectures of digital technology [17] as well as energy consumption, supply, and harvesting [18] [19] [20]. Many technical publications scratch economic opportunities, but do so usually only in the motivation section of their work. Although the technical aspects of the Internet of Things have been discussed for more than two decades, a profound economic discussion started only a few years ago.

The modern smartphone may be perceived as a catalyst not only for realworld IoT applications but also for discussions on the potential impact of the Internet of Things on industries, markets, companies, products, services, and consumers. The existing economic literature investigating IoT and smart products primarily focuses on research questions in the fields of management [21]-[26], transportation [27], supply chain management [28], market competition [2], new business models [29], consumers' attitudes toward autonomously acting products [30], the organizational structure of companies [31], production planning and control [32], privacy and secrecy [33], wearable devices [34], smart home, and ambient assisted living [35], just to name a few. From the perspective of marketing management, IoT products are of particular interest due to two new elementary functionalities we refer to as "product analytics" and "remote access" (see Figure 2).

Product analytics, on the one hand, relies on the autonomous collection of usage data from the customer's environment that provides companies with insights into the actual product usage. Remote access, on the other hand, offers options for remotely operating the IoT product, changing the parameters or adjustment of product attributes, activating and deactivating product functions, and controlling data flowing inbound to the IoT product. Either applied alone or together, product analytics and remote access open up a wide range of new opportunities for marketing management. 


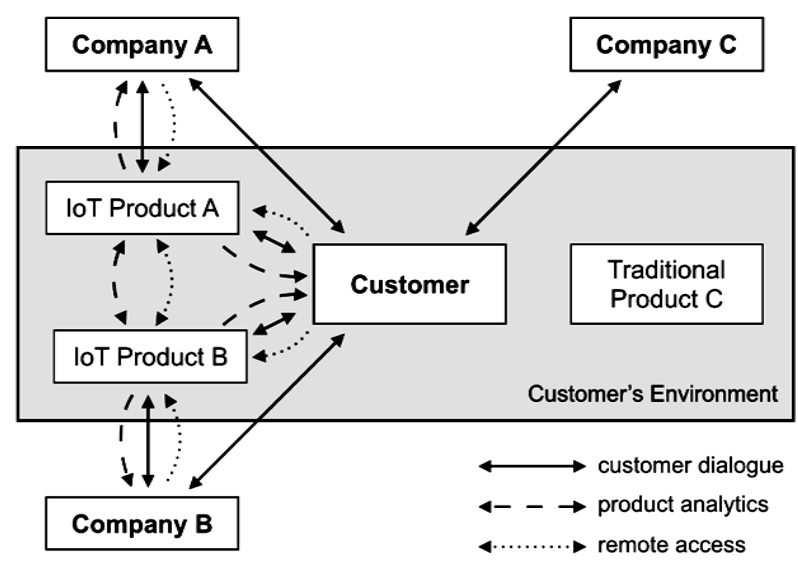

Figure 2. The flow of data beyond the point of sale with traditional products versus IoT products.

\section{Research Propositions for IoT-Related Marketing Management}

The key question here is how IoT products will affect marketing for consumer products with respect to management/practice and theory/research. In what follows, we develop and discuss ten research propositions in the fields of customer relationship management, product life cycle management, and business model development. The selected fields already host a growing number of IoT-related real-world phenomena and therefore constitute a promising starting point for analyzing the impact of IoT products on established theories.

\subsection{Customer Relationship Management (CRM)}

This field of research originally emerged from relationship management. Today, it deals with the integration of customer-related relationships and the use of systems that collect and analyze data across the company [36]. CRM systems therefore aim at linking and creating both company value and customer value along the value chain [37]. A milestone in the development of CRM was the paradigm change from product orientation to customer orientation [38]. Early work on CRM thus elaborated the idea of fulfilling customer needs instead of "just" selling products [39]. Advances in the CRM field then included the idea of building relationships. In this regard, theory development concerned building customer relationships [40], strategic partnerships, alliances, and networks [41], new paradigms from transactions to relationships [42], and service relationships [43] [44] [45]. Moreover, Peppers and Rogers [46] and Pine [47] steered the discussion of building relationships toward the concepts of one-to-one marketing and mass customization. Another stream of work on CRM emphasized the relevance of markets and dealt with market orientation [48] [49] and market focus [50]. This has evolved into market-based learning [51]. Corresponding learning relationships have been identified as key success factor in CRM that improves a company's ability to capture cross and upselling potential, reduce costs, provide word-of-mouth advertisements, increase switching costs, and much more [37] 


\section{[52] [53] [54] [55].}

Research on CRM received a significant boost from the special section on customer relationship management in the Journal of Marketing in 2005. In a CRM roadmap, Boulding et al. [36] stated that dual creation of value was the core of CRM. Dual creation or co-creation of value rests on creating and sharing economic rents for the company and the customer [56] [57] [58]. This idea has previously been elaborated by the "schemer schema" concept stating that companies maximize and extract the customer surplus [59]. Jayachandran et al. [60] developed a deeper conceptualization by considering five sub-processes that they call information reciprocity, information capture, information integration, information access, and information use. More recently, technological advancements significantly enriched the CRM tool box [37]: Since the 1980s, CRM decision makers experienced a sharp increase in the availability of customer data and they dealt with these data by capitalizing on the application of hard- and software to collect "data and activities surrounding the management of customer-firm interface" [36]. The Internet today allows for efficient communication and interaction with existing and potential buyers through email, social media, Facebook, YouTube, Twitter, blogs, and forums [61] [62] [63]. In addition to these Internet-based tools, the measurement process emerged as a vital element in any CRM system [56]. The application of modern Internet-based CRM solutions thus makes it easier for companies to have a customer relational orientation [60] [64].

One of the current thematic priorities in CRM is understanding the customer experience and the customer journey [65] [66]. With respect to the service delivery network, Tax et al. [67] emphasized that companies need to understand their role in the customer-defined service journey and to coordinate their activities with complementary providers. Other exemplary work in this direction applied the idea of the customer journey to test business models [68] and to determine the return on investment of CRM [69]. Technological advancement, customer experience, and customer journey show a strong overlap as modern CRM systems increase the number and versatility of a customer's direct or indirect interactions with the company [70]. These occasions of interaction are usually referred to as customer touch points [65] [71].

Research Proposition 1: With IoT products, customer touch points potentially become customer touch lines.

Customers may interact with a company through a multitude of touch points in multiple channels and media [65]. The set of touch points that customers experience with a product or the concerned company characterizes a customer journey [66]. The emergence of the Internet and the World Wide Web with all its applications augmented a company's set of options to interact with customers [72]. Lemon and Verhoef [65] even indicated an explosion in potential customer touch points regarding the availability of web-based and mobile applications. Current developments suggest that the Internet of Things will push this development process even further and turn customer touch points into what we call 
customer touch lines in the following. Instead of interacting with customers at discrete touch points, IoT products constantly capture product usage data and, depending on the specific purpose of the data collection, transmit these data to the company. With product analytics, companies can continuously monitor the customer journey in real time and use remote access to manage or even control the customer journey by changing product features or adapting the IoT products toward individual customer needs. Figure 3 illustrates the comparison of interactions between a customer and a company during the lifetime of a product from three different eras: (i) a traditional product from the pre-Internet era, (ii) a traditional product from the Internet era, and (iii) an IoT product from the IoT era.

For the sake of simplification, the customer journey starts with a touch point at the purchase stage for all products as described by Lemon and Verhoef [65]. In this hypothetical scenario, all products fail in the post-purchase stage resulting in the potential abandonment of product usage and a negative customer experience if the product failure is not fixed proactively by the company. In the pre-Internet era, the number of customer touch points is lowest, and the company usually does not receive any information about product failure and the customer stopping the use of the product. Common results are negative effects on customer experience and customer relationship. In the Internet era, the number of customer touch points increases significantly, as well as the likelihood that the company could detect and manage product failures [65]. In this scenario, the product usage may temporarily be interrupted by product repair and the corresponding opportunity to counteract the potentially decreasing customer relationship. An IoT product provides the company with real-time information on product usage resulting in a virtually continuous customer touch line. Product analytics allows the company to detect or even predict product failure before the customers become aware of it and, ideally, repair the IoT product with remote access. If remote repair is possible, the product usage is not interrupted or only temporarily interrupted, and the customer relationship remains unaffected. Car manufacturers are among the first to exploit customer touch lines and remote repair with respect to IT-related components of the vehicle. With a continuous exchange of data with the car via the Internet of Things, car manufacturers, such as Tesla Motors, are able to detect potential malfunctions and fix them remotely

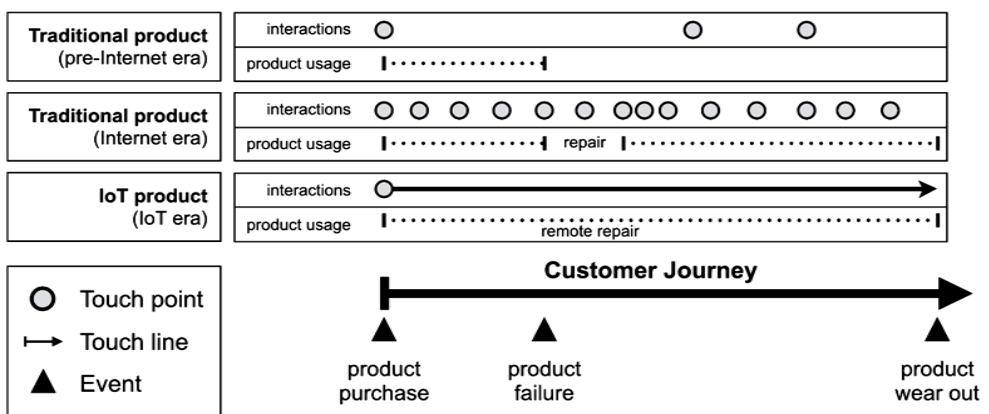

Figure 3. Customer touch line along the customer journey. 
with software updates. Further signs of the already ongoing evolution from touch points to touch lines can be witnessed in trends such as the "connected home" and "wearable devices." The acquisition of Nest Labs in 2014 and Android Inc. in 2005 provide Alphabet (Google) the opportunity to enrich their touch point-based customer journey from the web with customer touch lines from Android-operated smartphones and IoT-ready devices in customers' homes.

The concept of customer touch lines based on IoT products is expected to affect CRM in various ways. In accordance with the paradigm of ubiquitous computing by Weiser [6], "ubiquitous CRM" enabled by IoT products may lead to interactions between customers and companies disappearing into the fabric of everyday product usage. Instead of "hopping" along discrete customer touch points, we expect the idea of customer touch lines to leverage the concept of the "augmented" customer journey.

Research Proposition 2: With IoT products, the challenge of CRM systems switches from data collection to data handling.

Companies that acquire knowledge from customer data are more likely to show superior company performance [60] [73]. With traditional products, companies sometimes have the opportunity to unobtrusively collect customer data at the point of sale, for example, with video recording. However, traditional CRM concepts that aim at collecting data beyond the point of sale mainly rely on the customer's willingness to provide data [36], for example as part of a customer survey. In the IoT era, the production and collection of customer data in the post-purchase stage will become an integral part of product usage. Capturing and analyzing the actual usage of IoT products will be mandatory for a wide range of novel IoT functionalities, such as remote repair and customization of the product or usage-based pricing. The evolution of customer touch points to customer touch lines is accompanied by an unprecedented amount of data created in the customer's immediate environment. The emergence of "big marketing data" [74] shifts the challenge for CRM systems from data collection to efficient data analysis or, more precisely, to "marketing analytics" [72] [75]. Monitoring and managing the customer journey in real-time requires product analytics to handle large and often complex streams of data with high accuracy and minimal delay. Analytical processes that include manual human interactions are likely to be unsuitable for real-time product analytics. In this regard, significant progress in the research fields of machine learning, deep learning [76], and cognitive computing [77] continue to yield promising tools for analyzing large and even unstructured marketing data in real-time [75]. We expect marketing scholars to enrich CRM theory with concepts and methods from these fields. In addition to real-time processing, IoT-related data analysis also needs to be decentralized and, at least partly, be carried out on-board the IoT product. The technical requirement for decentralized data analysis is rooted in wireless communication of data accounting for the lion's share of total energy consumption of IoT products [12] [78]. The design of CRM systems and product analytics 
should therefore include at least rudimentary on-board data processing in order to prevent IoT products from sending large amounts of raw data. In general, sending, preferably aggregated, data only if required can significantly reduce the energy consumption of mobile and low-energy IoT products, such as wearables.

Research Proposition 3: IoT products are likely to increase the relevance of strategic customer behavior for CRM theory.

Literature on CRM has examined customer touch points regarding strategic customer behavior. If customers lose trust in the company and believe that their data is used to exploit them, customers will attempt to keep their data private or to distort the data [37] [56] [59]. Such concerns may lead customers to modify their own behavior for the sake of capturing a higher share of the value created in the dual creation process [36]. In other words, customers act strategically. In an experimental setting, Lewis [56] observed signs of strategic customer behavior at touch points for roughly $5 \%$ of the participating population. We expect strategic customer behavior to become more relevant for CRM theory in the IoT era for two reasons: First, the development from customer touch points to touch lines will offer customers more opportunities and, on various occasions, the need to behave strategically and, thus, increase the frequency of strategic behavior. A perceived need for strategic behavior may result, for example, from the usage of an IoT product in personal care. Second, the incentives for strategic customer behavior may increase in the future: IoT products unlock a variety of new opportunities for companies to link pricing, product features, or services directly to customers' monitored product usage behavior [23]. Customers may deliberately adapt product usage behavior to exploit the benefits linked to actual product usage. Pay-how-you-drive insurance is among the first examples of linking the monitored usage behavior of an IoT-ready car with the price premium. Insurance companies, such as Progressive, Metromile, Allstate, and Liberty Mutual in the United States and Telefo nica in Germany, take into account data on customers' driving style, including driving speed, braking behavior, and night driving, in order to determine individual and real-time insurance premiums (e.g., [79]). The automobile sector may be a blueprint for "pay-how-yougo" insurance for health, finance, and other spheres of human life. In 2015, the U.S. insurer John Hancock introduced life insurance that offers policy holders savings on premiums when the free Fitbit activity tracker shows indicators of a healthy lifestyle. The data source for pay-how-you-go insurance is likely to expand to other IoT products, such as IoT-ready kitchen appliances that may track customers' eating habits. Opportunistic customers may exploit premium benefits once they understand the tracking and analytics processes of the IoT product. CRM theory development should therefore address strategic customer behavior when product usage behavior is linked to the price or other attributes of the product or service offering.

Research Proposition 4: IoT products will facilitate the application of price discrimination strategies.

The implementation of one-to-one pricing strategies allows companies to 
maximize prices with respect to the price an individual customer is willing to pay. Price discrimination strategies are commonly used and found their way into online shops and online marketplaces. Early large-scale applications of dynamic pricing strategies on the Internet can be traced back to 2000 when Amazon.com was publicly criticized for discriminating customers with different prices for DVDs [80]. Today, price discrimination strategies are an inherent part of online shops and online marketplaces segmenting customers according to geolocation, HTTP referrer, browsing and purchase history, web browser, operating system, and other features [81]. However, the application of one-to-one pricing strategies can cause concerns about favoritism when customers perceive to be treated unequally. Such concerns may negatively affect the customer journey and potentially result in customers opting out. The problem of favoritism was also addressed by Nguyen and Mutum [37] who suggested building trust to reduce negative customer perceptions. In this regard, IoT products offer a new approach as they can be customized to individual customer needs at a large scale [2] [23] [25]. In the past, mass customization of traditional products took place primarily at the hardware level, for example, enabled by computer-aided design or computer-aided manufacturing [82]. With the emergence of the Internet, customization has become increasingly popular for product differentiation beyond the purchase stage [83] [84] [85]. The more differentiated the products, the more difficult product comparisons potentially become. The interaction of product analytics and remote access allows companies to customize and personalize IoT products to a degree that has not been available thus far. This effect can even be leveraged with smart products that autonomously learn and adapt product functionalities according to individual customer preferences [86] such as Nest's Learning Thermostat. Using machine learning techniques, for example, smart products may develop unique customer profiles and product features, which potentially become more distinct with increasing amounts of interaction and training data. Accordingly, marketing scholars focusing on CRM theory development should further investigate the opportunities and threats of mass customization of IoT products to reduce negative effects of favoritism.

Research Proposition 5: IoT products will create new kinds of customer switching costs.

Customer switching costs have been a popular research subject in various studies on customer retention, competition, enterprise profitability, and others [87]-[92]. Switching costs can be interpreted as "onetime costs that customers associate with the process of switching from one provider to another" [93]. The impediments for customers to change their providers can include search costs, transaction costs, learning costs, loyalty discounts, customer habits, emotional cost, cognitive effort, as well as financial, social, and psychological risk [88]. IoT products promote mass customization beyond the point of sale, which, in turn, can increase the economic switching costs for customers [2] [23] [25] [94]. When product usage is automatically tracked and stored, customers possess a rich history of personal data that potentially includes profiles, conversations, ac- 
tivities, or states of health. These data are valuable not only to companies but also to the customers themselves. The Nike+ Run Club offers customers a wide range of services based on workout data automatically stored in the cloud. Customers can track their progress, compare the results with friends, and receive customized coaching. In the case of provider switching, these data, normally, cannot be transferred among companies and are lost. The longer or more intense an IoT product has been used, the more user-centric longitudinal data customers will lose when they change providers [2] [95]. In the cloud computing literature, this kind of switching cost is subsumed under a concept often referred to as vendor lock-in [96]. Switching costs based on usage data open up new opportunities for customer retention especially with products that lack relevant switching costs in traditional settings such as low-involvement or white-label products. IoT versions of these products can build up significant switching costs with usage data collected over time. Again, we believe that this effect will become more important with smart products, because, in addition to data, customers may also forfeit some of the product utility relying on the self-learning capabilities of the smart product. Switching to a "raw" smart product (with the same basic functionality) from another provider then requires customers to train the new smart product anew over days, weeks, or even months. CRM-related research should take into account these new types of switching costs coming along with IoT and smart products.

Research Proposition 6: With IoT products, new indicators of company performance become available for CRM models.

Most empirical studies on CRM consider company performance in one way or the other. Ryals [57] and Cao and Gruca [97], for example, used profit, Lewis [56] used revenues, Gustafsson et al. [98] used retention, and Srinivasan and Moorman [64] and Mithas et al. [73] used satisfaction as proxy variables for company performance. IoT products can supply CRM models with various new indicators for company performance, such as the intensity and type of product usage (e.g., number of features used, frequency of product usage, share of customers using the product correctly) or the number and duration of usage terminations. Performance indicators based on actual product usage are commonly used in web and mobile applications. Product analytics may serve as a means for an even more detailed customer segmentation. The percentage of paying customers and the amount of usage data captured per customer are promising examples of corresponding IoT-related performance indicators. We therefore suggest their incorporation in order to improve the explanatory and predictive accuracy of CRM models.

\subsection{Product Life Cycle Management}

The product life cycle (PLC) emanates from the theory of diffusion and adoption of innovations and describes the lifetime of a product in stages from introduction to growth and maturity to decline [99]. The basic PLC is usually represented by a bell-shaped curve [100] [101]. However, several variations of this basic 
structure, such as linear [102], cycle-recycle [103] [104], plateau [101], and maturity shapes [105] for different product categories and industries can also be found in literature. The early work on PLC theory focused on the identification and empirical validation of factors that determine the specific shape and length of the PLC. Among the most popular factors are sales of closely related products [100], changes in market and economic conditions, reactions to competitors [106], product performance, permanence of customers [107], the rate of technological change, the rate of market acceptance, and the ease of competitive entry [108]. A stream of subsequent work enriched the PLC theory by the subject of repeat purchases based on replacement [109] [110] [111] [112] and upgrade [113] [114]. While the former represents product sales as a result of the replacement of worn out products, the latter refers to the replacing of fully functioning but technologically outdated products with a newer version that offers a higher perceived utility. The academic work on repeat purchases based on upgrades resulted in the theory of generation substitution that has been developed to study the market diffusion and PLCs of products with multiple generations [115] [116]. In this regard, the Internet of Things is about to affect or even change PLC theory in several ways.

Research Proposition 7: IoT products may come without product generations.

Generation substitution models tend to emphasize repeat purchases from wear-out effects less, arguing that technological aging outweighs the durability of products [117]. Especially technology-rich and innovation-driven products, such as personal computers and smartphones, are predominantly replaced because they are technologically outdated although still fully functional. In the future, IoT products are likely to have no regular product generations, because the utility IoT products generate for customers is increasingly based on software that is less prone to technological aging and because product analytics and remote access allow the company to continuously monitor and update the software of IoT products. The more software accounts for a product's basic utility, the less relevant repurchases based on hardware upgrades become. Virtual personal assistants such as Siri and Google Now herald the emergence of generation-free products in the Internet of Things. Although personal assistants require sensors to acquire data (e.g., via microphone and GPS), their functionality is almost solely based on software that is predominantly operated in the cloud. Thus, many virtual personal assistants are backward compatible and run on smartphones from older generations. Future PLC theory development should address the increased utilization of software and cloud-based product features that have virtually no product generations in the conventional sense.

Research Proposition 8: PLC models need to consider gradual adoption of IoT products.

Existing PLC models usually focus on the initial purchase of a product, that is, the adoption process only [118]-[125], and subsequent repeat purchases [111] [114] [126] as the pivotal reference values. The absence of regular generations 
for IoT products renders repeat purchases obsolete for IoT-related PLC models. In the future, IoT products may allow for gradual adoption when marketed with business models with at least two intensities of product adoption. The freemium business model, for instance, offers customers gradual (in this case, dual) adoption of a free basic version and a paid premium version of the product (free + premium $=$ freemium). A popular example of a product marketed with a freemium business model is the Swedish music streaming provider Spotify. While its basic version is free to use, customers need to pay a subscription fee for the premium version.

Although physical IoT products have not yet been marketed with a freemium business model to the best of our knowledge, we believe that this is just a matter of time. With product analytics and remote access, IoT products can potentially become the object of business models that allow for gradual adoption. However, regarding PLC theory, the questions remain, how gradual adoption develops across life cycle stages and how switching costs and other aspects of the PLC affect different types of product adopters. Accordingly, future research should further elaborate the impact of gradual adoption on PLC theory.

\subsection{Business Model Development}

Business models first gained attention in academia in the context of information technology and were initially used in terms of process models [127]. The emergence of electronic commerce reshaped the view on business models from an operative plan into an "integrated presentation of the company organization" [128]. Some academic work aimed at separating the concept of business models from well-established fields, such as organization strategy, business strategy, and planning [129] [130] [131] [132]. The research field of business models is still in an early stage and largely builds on conceptual and case study work [128]. In the following, we focus on revenue generation and pricing [133] [134] [135] [136] [137] as well as on joint value creation [129] [138] [139] [140].

Research Proposition 9: The Internet of Things facilitates the application of Internet-based business models with physical products.

Traditional products are commonly marketed with a transaction-dependent revenue model [128]. However, in the past two decades the Internet paved the way for a number of new business models that have been successfully executed by pioneers, such as Alphabet (Google), Amazon, and Facebook [141]. New Internet-based business models often rest upon software that runs at negligible operation costs, with virtually endless scalability, and that provides access to usage data. The web enabled a variety of new business models such as Software-as-a-Service (SaaS), freemium, and other Internet-based business models [2] [3] [21] [23] [142] [143] [144] [145]. With the expansion of the Internet to the physical world, new Internet-based business models become applicable for the marketing of physical products [146]. By 2018, about 28\% of applications running in enterprises around the world are predicted to be based on SaaS business models, up from 17\% in 2013 [143]. Similarly, Product-as-a-Service (PaaS) 
is on the verge of becoming a popular business model for IoT products. In the automotive sector, visionary pioneers are discussing equipping cars with virtually uniform engines and enabling an individual access to variable engine performance via the Internet ("horsepower-on-demand"). In such a scenario, customers could pay, for example, a monthly fee based on the performance they demand from the engine ("Pay what you demand"). Another promising business model for IoT products is "in-product purchases". This business model leans on the concept of in-app purchases from mobile applications that usually generate micropayments that will account for estimated revenues of US\$ 36 billion in 2017 worldwide, up from about US\$ 2 billion in 2012 [147]. As one of the currently most successful mobile apps, Pokémon Go is free to download and offers in-app purchases for additional items in the game. As of August 2016, Pokémon Go had generated US\$ 85 million within a time period of two months from such in-app purchases on the iOS platform alone [148]. IoT products can also serve as vehicles to offer in-product purchases. The German kitchen equipment manufacturer Vorwerk is among the first to apply in-product purchases (e.g., personalized recipes and cooking courses) in their IoT-ready kitchen machine Thermomix. Accordingly, we suggest that academic researchers systematically explore and evaluate the transfer of Internet-based business models from web and mobile applications to IoT products.

Research Proposition 10: IoT products facilitate joint value creation with third parties.

As part of the business model concept proposed by Wirtz et al. [128], the network model represents a management tool for checking and controlling the value distribution in a joint value creation setting [149]. In the Internet era, companies can create value for customers through information drawn from other customers [36]. A popular example from the field of online shops are product recommendations generated from purchase decisions of other customers with a similar user and demand profile. With IoT products, companies can include the product usage behavior of other customers to increase the value of the focal customer. The usage data captured by one IoT product can then help improve other IoT products of this kind (e.g., in the field of IoT-based fitness training using connected activity trackers). We expect this opportunity to be even greater with smart products. If one smart product learns something from some customer, virtually all smart products of this kind may learn and may potentially increase the value for their particular users. We refer to this as the passive joint value creation process enabled by product analytics. Marketing research should investigate in-depth the effects of passive joint value creation on other components of business models.

\section{Conclusions and Implications}

In the past two decades, the Internet has fundamentally changed marketing theory. With the current expansion from the virtual world to physical objects, the Internet is undergoing a significant expansion that is about to affect market- 
ing theory and management once again. Following the idea of linking physical and virtual objects, the emerging Internet of Things is giving birth to a new category of products that autonomously collect and share data. These IoT products provide a new and potentially "game-changing" source of data [31] [150]. As data is the fuel that runs the marketing engine, marketing theories and concepts need to be put to the test for the emerging era of the Internet of Things. The paper at hand contributes to this research by developing and discussing research propositions concerning the relationship between IoT (consumer) products and marketing management and theory, respectively.

IoT products provide two novel functionalities: product analytics and remote access. Product analytics refers to data that has been collected by the IoT product during product usage and is shared with customers, companies, and/or other IoT products. The concept of product analytics constitutes an extension of the already established approaches from web analytics and mobile analytics to connected everyday products. The "counterpart" to product analytics is remote access, which refers to data that (remotely) flows to the IoT product. Product analytics and remote access, either as stand-alone functionalities or in combination, offer a broad range of new opportunities for marketing management. In our analysis, we developed and discussed ten research propositions (see Table 1) in three main fields of marketing, namely, customer relationship management, product life cycle management, and business model development, which are currently experiencing the highest impacts from the Internet of Things.

The IoT phenomena and their impact on well-established marketing theories and concepts are not separate events within the investigated fields but instead are harbingers of a more fundamental and paradigm-changing development. With IoT-ready everyday products, customers are permanently surrounded by a variety of sensors and Internet access points enabling a permanent connection with companies. Accordingly, the core paradigms in marketing theory once evolved from selling products to fulfilling customer needs [40] must be further

Table 1. Ten propositions on the impact of the Internet of Things on marketing management.

\section{Customer Relationship Management:}

With IoT products, customer touch points potentially become customer touchlines.

With IoT products, the challenge of CRM systems will switch from data collection to data handling. IoT products are likely to increase the relevance of strategic customer behavior for CRM theory.

IoT products will facilitate the application of price discrimination strategies.

IoT products will create new kinds of customer switching costs.

With IoT products, new indicators for company performance become available for CRM models.

Product Life Cycle Management:

IoT products may come without product generations.

PLC models need to consider gradual adoption of IoT products.

Business Model Development:

The IoT facilitates the application of Internet-based business models with physical products.

IoT products facilitate joint value creation with third parties. 
developed in this respect. In particular, we expect that the emerging IoT era will give rise to a new paradigm that will be dominated by ecosystems [151] [152]. When customers use (and not necessarily own) an IoT product or a smart product, in most cases they automatically opt for being connected to a particular ecosystem which also implies the choice of specific providers. The customer journey from the viewpoint of a single company may therefore evolve to a customer journey in an ecosystem that is operated by a network of (possibly even competing) companies. Products themselves, at least regarding the hardware, thus turn into vehicles customers use to get access to an ecosystem. We have already witnessed the development of such competing ecosystems in personal computers (e.g., Windows and MacOS) and mobile smartphones (e.g., iOS and Android). Currently, we are observing the first indications of emerging ecosystems for wearable devices, smart home applications, self-driving cars, and other consumer products.

Future research therefore needs to expand the prevailing conceptual analysis in its breadth and depth: First, IoT products are likely to affect theories and concepts from other marketing fields in similar ways. Promising research fields are marketing mix and brand management (e.g., regarding the influence of product smartness on the willingness to pay). Second, the presented research propositions must be investigated empirically, partly by making use of long-term studies. In this regard, experimental settings can be used to test the increase in strategic customer behavior when customers use IoT products. Third, future research should further study the impact of smart products on well-established marketing theories. In addition to connectivity, smart products possess the ability of decision making that will likely affect customers' purchase decision making and product usage. Fourth, it would be worthwhile to more thoroughly investigate the impact of the Internet of Things not only in a business-to-consumer context as in the paper at hand, but also in the business-to-business or consumer-to-consumer field (for recent work on IoT-based business models in industrial markets see [153]). Finally, IoT products are expected to even more become part of service offerings which adds another appealing research perspective.

\section{Acknowledgements}

We sincerely thank Wilhelm Klat for his contribution to an earlier version of this paper.

\section{References}

[1] Bauer, S.R. and Mead, P. (1995) After You Open the Box: Making Smart Products More Usable, Useful, and Desirable Through Interactive Technology. Design Management Journal, 6, 21-26. https://doi.org/10.1111/j.1948-7169.1995.tb00453.x

[2] Porter, M.E. and Heppelmann, J.E. (2014) How Smart, Connected Products Are Transforming Competition. Harvard Business Review, 92, 64-88.

[3] Watson, R.T., Pitt, L.F., Berthon, P. and Zinkhan, G.M. (2002) U-Commerce: Expanding the Universe of Marketing. Journal of the Academy of Marketing Science, 
30, 333-347. https://doi.org/10.1177/009207002236909

[4] Ng, I.C.L. and Wakenshaw, S.Y.L. (2017) The Internet-of-Things: Review and Research Directions. International Journal of Research in Marketing, 34, 3-21. https://doi.org/10.1016/j.ijresmar.2016.11.003

[5] Kannan, P.K. and Li, H.A. (2017) Digital Marketing: A Framework, Review and Research Agenda. International Journal of Research in Marketing, 34, 22-45. https://doi.org/10.1016/j.ijresmar.2016.11.006

[6] Weiser, M. (1991) The Computer for the 21st Century. Scientific American, 265, 94-104. https://doi.org/10.1038/scientificamerican0991-94

[7] Aarts, E., Harwig, R. and Schuurmans, M. (2002) Ambient Intelligence. In: Denning, P.J., Ed., The Invisible Future: The Seamless Integration of Technology in Everyday Life, McGraw-Hill, Columbus, 235-250.

[8] Acampora, G., Cook, D.J., Rashidi, P. and Vasilakos, A.V. (2013) A Survey on Ambient Intelligence in Healthcare. Proceedings of the IEEE, 101, 2470-2494. https://doi.org/10.1109/JPROC.2013.2262913

[9] Posland, S. (2009) Ubiquitous Computing: Smart Devices, Environments and Interactions. Wiley, Hoboken. https://doi.org/10.1002/9780470779446

[10] Cocchia, A. (2014) Smart and Digital City: A Systematic Literature Review. In: Dameri, R.P. and Rosenthal-Sabroux, C., Eds., Smart City: How to Create Public and Economic Value with High Technology in Urban Space, Springer, Cham, 13-43. https://doi.org/10.1007/978-3-319-06160-3_2

[11] Akyildiz, I.F., Su, W., Sankarasubramaniam, Y. and Cayirci, E. (2002) Wireless Sensor Networks: A Survey. Computer Networks, 38, 393-422. https://doi.org/10.1016/S1389-1286(01)00302-4

[12] Chong, C.Y. and Kumar, S.P. (2003) Sensor Networks: Evolution, Opportunities, and Challenges. Proceedings of the IEEE, 91, 1247-1256. https://doi.org/10.1109/JPROC.2003.814918

[13] Lewis, F.L. (2005) Wireless Sensor Networks. In: Cook, D.J. and Das, S.K., Eds., Smart Environments. Technologies, Protocols, and Applications, Wiley, Hoboken, 13-46. https://doi.org/10.1002/047168659X.ch2

[14] Meyer, G.G., Främling, K. and Holmström, J. (2009) Intelligent Products: A Survey. Computers in Industry, 60, 137-148. https://doi.org/10.1016/j.compind.2008.12.005

[15] Pantelopoulos, A. and Bourbakis, N.G. (2010) A Survey on Wearable Sensor-Based Systems for Health Monitoring and Prognosis. IEEE Transactions on Systems, Man, and Cybernetics-Part C: Applications and Reviews, 40, 1-12. https://doi.org/10.1109/TSMCC.2009.2032660

[16] Su, W., Akan, Ö.B. and Cayirci, E. (2004) Communication Protocols for Sensor Networks. In: Raghavendra, C.S., Sivalingam, K.M. and Znati, T., Eds., Wireless Sensor Networks, Kluwer, Norwell, 21-50. https://doi.org/10.1007/1-4020-7884-6_2

[17] Yoo, Y., Boland, R.J., Lyytinen, K. and Majchrzak, A. (2012) Organizing for Innovation in the Digitized World. Organization Science, 23, 1398-1408. https://doi.org/10.1287/orsc.1120.0771

[18] Mitton, N. and Wolhuter, R. (2014) Energy Harvesting in Wireless Sensor Networks. In: Chen, J., He, S. and Sun, Y., Eds., Rechargeable Sensor Networks. Technology, Theory, and Application, World Scientific, Hackensack, 205-220. https://doi.org/10.1142/9789814525466_0006

[19] Raghunathan, V., Schurgers, C., Park, S. and Srivastava, M. (2006) Energy-Efficient Design of Wireless Sensor Nodes. In: Raghavendra, C.S., Sivalingam, K.M. and Znati, T., Eds., Wireless Sensor Networks, Springer, New York, 51-69. 
[20] Shebli, F., Dayoub, I., M’foubat, A.O., Rivenq, A. and Rouvaen, J.M. (2007) Minimizing Energy Consumption within Wireless Sensor Networks Using Optimal Transmission Range between Nodes. Proceedings of the IEEE International Conference on Signal Processing and Communications (ICSPC), Dubai, 24-27 November 2007, 105-108.

[21] Allmendinger, G. and Lombreglia, R. (2005) Four Strategies for the Age of Smart Services. Harvard Business Review, 83, 131-134.

[22] Dhebar, A. (1996) Information Technology and Product Policy: "Smart" Products. European Management Journal, 14, 477-485. https://doi.org/10.1016/0263-2373(96)00041-2

[23] Körling, M. (2012) Smart Products: Why Adding a Digital Side to a Toothbrush Could Make a Lot of Sense. Ericsson Business Review, 18, 26-31.

[24] Kowatsch, T., Maass, W., Filler, A. and Janzen, S. (2008) Knowledge-Based Bundling of Smart Products on a Mobile Recommendation Agent. Proceedings of the 7 th International Conference on Mobile Business (ICMB 08), Barcelona, 7-8 July 2008, 181-190.

[25] Mayer, P. (2010) Economic Aspects of Smart Products. White Paper, Institute of Technology Management, University of St. Gallen, St. Gallen.

[26] Resatsch, F. (2010) Ubiquitous Computing: Developing and Evaluating Near Field Communication Applications. Springer, Wiesbaden.

https://doi.org/10.1007/978-3-8349-8683-2

[27] Meyer, G.G., Buijs, P., Szirbik, N.B. and Wortmann, J.C. (2014) Intelligent Products for Enhancing the Utilization of Tracking Technology in Transportation. International Journal of Operations \& Production Management, 34, 422-446. https://doi.org/10.1108/IJOPM-11-2012-0530

[28] Zhou, L., Chong, A.Y.L. and Ngai, E.W.T. (2015) Supply Chain Management in the Era of the Internet of Things. International Journal of Production Economics, 195, 1-3. https://doi.org/10.1016/j.ijpe.2014.11.014

[29] Glova, J., Sabol, T. and Vajda, V. (2014) Business Models for the Internet of Things Environment. Procedia Economics and Finance, 15, 1122-1129. https://doi.org/10.1016/S2212-5671(14)00566-8

[30] Rijsdijk, S.A. and Hultink, E.J. (2009) How Today's Consumers Perceive Tomorrow's Smart Products. Journal of Product Innovation Management, 26, 24-42. https://doi.org/10.1111/j.1540-5885.2009.00332.x

[31] Porter, M.E. and Heppelmann, J.E. (2015) How Smart, Connected Products Are Transforming Companies. Harvard Business Review, 93, 1-37.

[32] Meyer, G.G., Wortmann, J.C. and Szirbik, N.B. (2011) Production Monitoring and Control with Intelligent Products. International Journal of Production Research, 49, 1303-1317. https://doi.org/10.1080/00207543.2010.518742

[33] Weinberg, B.D., Milne, G.R., Andonova, Y.G. and Hajjat, F.M. (2015) Internet of Things: Convenience vs. Privacy and Secrecy. Business Horizons, 58, 615-624. https://doi.org/10.1016/j.bushor.2015.06.005

[34] Robson, K., Pitt, L.F. and Kietzmann, J. (2016) APC Forum: Extending Business Values through Wearables. MIS Quarterly Executive, 15, 167-177.

[35] Röcker, C. (2013) Intelligent Environments as a Promising Solution for Addressing Current Demographic Changes. International Journal of Innovation, Management and Technology, 4, 76-79.

[36] Boulding, W., Staelin, R., Ehret, M. and Johnston, W.J. (2005) A Customer Relationship Management Roadmap: What Is Known, Potential Pitfalls, and Where to 
Go. Journal of Marketing, 69, 155-166. https://doi.org/10.1509/jmkg.2005.69.4.155

[37] Nguyen, B. and Mutum, D.S. (2012) A Review of Customer Relationship Management: Successes, Advances, Pitfalls and Futures. Business Process Management Journal, 18, 400-419. https://doi.org/10.1108/14637151211232614

[38] Levitt, T. (1960) Marketing Myopia. Harvard Business Review, 38, 45-56.

[39] Kotler, P. (1967) Marketing Management: Analysis, Planning, and Control. Prentice-Hall, Upper Saddle River.

[40] Berry, L.L. (1995) Relationship Marketing of Services: Growing Interest, Emerging Perspectives. Journal of the Academy of Marketing Science, 23, 236-245. https://doi.org/10.1177/009207039502300402

[41] Grönross, C. (1994) Quo Vadis, Marketing? Toward a Relationship Marketing Paradigm. Journal of Marketing Management, 10, 347-360. https://doi.org/10.1080/0267257X.1994.9964283

[42] Webster, F.E. (1992) The Changing Role of Marketing in the Corporation. Journal of Marketing, 56, 1-17. https://doi.org/10.2307/1251983

[43] Bolton, R.N. and Lemon, K.N. (1999) A Dynamic Model of Customers' Usage of Services: Usage as an Antecedent and Consequence of Satisfaction. Journal of Marketing Research, 36, 171-186. https://doi.org/10.2307/3152091

[44] Rust, R.T. and Zahorik, A.J. (1993) Customer Satisfaction, Customer Retention, and Market Share. Journal of Retailing, 69, 193-215. https://doi.org/10.1016/0022-4359(93)90003-2

[45] Rust, R.T., Zahorik, A.J. and Keiningham, T.L. (1995) Return on Quality (ROQ): Making Service Quality Financially Accountable. Journal of Marketing, 59, 58-70. https://doi.org/10.2307/1252073

[46] Peppers, D. and Rogers, M. (1993) The One to One Future: Building Relationships One Customer at a Time. Currency Doubleday, New York.

[47] Pine, J.B. (1993) Mass Customization: The New Frontier of Business Competition. Harvard University Press, Boston.

[48] Kohli, A.K. and Jaworski, B.J. (1990) Market Orientation: The Construct, Research Propositions, and Managerial Implications. Journal of Marketing, 5, 1-18. https://doi.org/10.2307/1251866

[49] Narver, J.C. and Slater, S.F. (1990) The Effect of a Market Orientation on Business Profitability. Journal of Marketing, 20, 20-35. https://doi.org/10.2307/1251757

[50] Day, G.S. (1994) The Capabilities of Market-Driven Organizations. Journal of Marketing, 58, 37-52. https://doi.org/10.2307/1251915

[51] Slater, S.F. and Narver, J.C. (1995) Market Orientation and the Learning Organization. Journal of Marketing, 59, 63-74. https://doi.org/10.2307/1252120

[52] Bowen, J.T. and Shoemaker, S. (1998) Loyalty: A Strategic Commitment. Cornell Hotel and Restaurant Administration Quarterly, 39, 12-25. https://doi.org/10.1177/001088049803900104

[53] Galitsky, B. and De la Rosa, J.L. (2011) Concept-Based Learning of Human Behavior for Customer Relationship Management. Information Sciences, 181, 20162035. https://doi.org/10.1016/j.ins.2010.08.027

[54] Lusch, R.F., Vargo, S.L. and Tanniru, M. (2010) Service, Value Networks and Learning. Journal of the Academy of Marketing Science, 38, 19-31. https://doi.org/10.1007/s11747-008-0131-Z

[55] Payne, A. and Frow, P. (2005) A Strategic Framework for Customer Relationship Management. Journal of Marketing, 69, 167-176. 
https://doi.org/10.1509/jmkg.2005.69.4.167

[56] Lewis, M. (2005) Incorporating Strategic Consumer Behavior into Customer Valuation. Journal of Marketing, 69, 230-238. https://doi.org/10.1509/jmkg.2005.69.4.230

[57] Ryals, L. (2005) Making Customer Relationship Management Work: The Measurement and Profitable Management of Customer Relationships. Journal of Marketing, 69, 252-261. https://doi.org/10.1509/jmkg.2005.69.4.252

[58] Thomas, J.S. and Sullivan, U.Y. (2005) Managing Marketing Communications with Multichannel Customers. Journal of Marketing, 69, 239-251.

https://doi.org/10.1509/jmkg.2005.69.4.239

[59] Wright, P. (1986) Schemer Schema: Consumers' Intuitive Theories about Marketers' Influence Tactics. Advances in Consumer Research, 13, 1-3.

[60] Jayachandran, S., Sharma, S., Kaufman, P. and Raman, P. (2005) The Role of Relational Information Processes and Technology Use in Customer Relationship Management. Journal of Marketing, 69, 177-192. https://doi.org/10.1509/jmkg.2005.69.4.177

[61] Greenberg, P. (2009) CRM at the Speed of Light: Social CRM 2.0 Strategies, Tools, and Techniques for Engaging Your Customers. 4th Edition, McGraw-Hill, Emeryville.

[62] Lamberton, C. and Stephen, A.T. (2016) A Thematic Exploration of Digital, Social Media, and Mobile Marketing: Research Evolution from 2000 to 2015 and an Agenda for Future Inquiry. Journal of Marketing, 80, 146-172.

https://doi.org/10.1509/jm.15.0415

[63] Quinton, S. and Harridge-March, S. (2010) Relationships in Online Communities: The Potential for Marketers. Journal of Research in Interactive Marketing, 4, 59-73. https://doi.org/10.1108/17505931011033560

[64] Srinivasan, R. and Moorman, C. (2005) Strategic Firm Commitments and Rewards for Customer Relationship Management in Online Retailing. Journal of Marketing, 69, 193-200. https://doi.org/10.1509/jmkg.2005.69.4.193

[65] Lemon, K.N. and Verhoef, P.C. (2016) Understanding Customer Experience throughout the Customer Journey. Journal of Marketing, 80, 69-96. https://doi.org/10.1509/jm.15.0420

[66] Rawson, A., Duncan, E. and Jones, C. (2013) The Truth about Customer Experience. Harvard Business Review, 91, 1-10.

[67] Tax, S.S., McCutcheon, D. and Wilkinson, I.F. (2013) The Service Delivery Network (SDN): A Customer-Centric Perspective of the Customer Journey. Journal of Service Research, 16, 454-470. https://doi.org/10.1177/1094670513481108

[68] Norton, D.W. and Pine II, B.J. (2013) Using the Customer Journey to Road Test and Refine the Business Model. Strategy \& Leadership, 41, 12-17. https://doi.org/10.1108/10878571311318196

[69] Ang, L. and Buttle, F.A. (2002) ROI on CRM: A Customer-Journey Approach. Proceedings of the Industrial Marketing and Purchasing Conference, Perth, 11-13 December 2002, 1-20.

[70] Foss, B., Stone, M. and Ekinci, Y. (2008) What Makes for CRM System Success or Failure? Database Marketing \& Customer Strategy Management, 15, 68-78. https://doi.org/10.1057/dbm.2008.5

[71] Fickel, L. (1999) Know Your Customer. CIO Magazine, 12, 62-72.

[72] Verhoef, P.C., Kannan, P.K. and Inman, J.J. (2015) From Multi-Channel Retailing to Omni-Channel Retailing: Introduction to the Special Issue on Multi-Channel Retailing. Journal of Retailing, 91, 174-181. 
https://doi.org/10.1016/j.jretai.2015.02.005

[73] Mithas, S., Krishnan, M.S. and Fornell, C. (2005) Why do Customer Relationship Management Applications Affect Customer Satisfaction? Journal of Marketing, 69, 201-209. https://doi.org/10.1509/jmkg.2005.69.4.201

[74] Kaur, P.D. and Arora, S. (2015) Regression and Endogeneity Bias in Big Marketing Data. Procedia Computer Science, 70, 41-47. https://doi.org/10.1016/j.procs.2015.10.025

[75] Wedel, M. and Kannan, P.K. (2016) Marketing Analytics for Data-Rich Environments. Journal of Marketing, 80, 97-121. https://doi.org/10.1509/jm.15.0413

[76] LeCun, Y., Bengio, Y. and Hinton, G. (2015) Deep Learning. Nature, 521, 436-444. https://doi.org/10.1038/nature14539

[77] Modha, D.S., Ananthanarayanan, R., Esser, S.K., Ndirango, A., Sherbondy, A.J. and Singh, R. (2015) Cognitive Computing. Communications of the ACM, 54, 62-71. https://doi.org/10.1145/1978542.1978559

[78] Lajara, R.J., Perez-Solano, J.J. and Pelegrí-Sebastia, J. (2015) A Method for Modeling the Battery State of Charge in Wireless Sensor Networks. IEEE Sensors Journal, 15, 1186-1197. https://doi.org/10.1109/JSEN.2014.2361151

[79] Telefónica, P.H.Y.D. (2013) Telefónica Insurance Telematics: New M2M Solution Can Reduce Car Insurance Costs.

https://www.telefonica.de/fixed/news/5030/telefonica-insurance-telematics-new-m2 -m-solution-can-reduce-car-insurance-costs.html. Accessed 21 December 2016.

[80] Feinberg, F.M., Krishna, A. and Zhang, Z.J. (2002) Do We Care What Others Get? A Behaviorist Approach to Targeted Promotions. Journal of Marketing Research, 39, 277-292. https://doi.org/10.1509/jmkr.39.3.277.19108

[81] Hannak, A., Soeller, G., Lazer, D., Mislove, A. and Wilson, C. (2014) Measuring Price Discrimination and Steering on E-Commerce Web Sites. Proceedings of the Conference on Internet Measurement Conference, Vancouver, 5-7 November 2014, 305-318. https://doi.org/10.1145/2663716.2663744

[82] Davis, S.M. (1989) From "Future Perfect": Mass Customization. Planning Review, 17, 16-21. https://doi.org/10.1108/eb054249

[83] Fan, H. and Pool, M.S. (2006) What Is Personalization? Perspectives on the Design and Implementation of Personalization in Information Systems. Journal of Organizational Computing and Electronic Commerce, 16, 179-202. https://doi.org/10.1080/10919392.2006.9681199

[84] Kwon, K. and Kim, C. (2012) How to Design Personalization in a Context of Customer Retention: Who Personalizes What and to What Extent? Electronic Commerce Research and Applications, 11, 101-116. https://doi.org/10.1016/j.elerap.2011.05.002

[85] Tam, K.Y. and Ho, S.Y. (2006) Understanding the Impact of Web Personalization on User Information Processing and Decision Outcomes. Management Information Quarterly, 30, 865-890.

[86] Rijsdijk, S.A., Hultink, E.J. and Diamantopoulos, A. (2007) Product Intelligence: Its Conceptualization, Measurement and Impact on Consumer Satisfaction. Journal of the Academy of Marketing Science, 35, 340-356. https://doi.org/10.1007/s11747-007-0040-6

[87] Beggs, A. and Klemperer, P. (1992) Multi-Period Competition with Switching Costs. Econometrica, 60, 651-666. https://doi.org/10.2307/2951587

[88] Fornell, C. (1992) A National Customer Satisfaction Barometer: The Swedish Experience. Journal of Marketing, 56, 6-21. https://doi.org/10.2307/1252129

[89] Karakaya, F. and Stahl, M.J. (1989) Barriers to Entry and Market Entry Decisions in 
Consumer and Industrial Goods Markets. Journal of Marketing, 53, 80-91. https://doi.org/10.2307/1251415

[90] Kerin, R.A., Varadarajan, P.R. and Peterson, R.A. (1992) First-Mover Advantage: A Synthesis, Conceptual Framework, and Research Propositions. Journal of Marketing, 56, 33-52. https://doi.org/10.2307/1251985

[91] Porter, M.E. (1980) Competitive Strategy: Techniques for Analyzing Industries and Competitors. The Free Press, New York.

[92] Schmalensee, R. (1982) Product Differentiation Advantages of Pioneering Brands. American Economic Review, 72, 349-365.

[93] Burnham, T.A., Freis, J.K. and Mahajan, V. (2003) Consumer Switching Costs: A Typology, Antecedents, and Consequences. Journal of the Academy of Marketing Science, 31, 109-126. https://doi.org/10.1177/0092070302250897

[94] Cao, H. and Folan, P. (2011) Product Life Cycle: The Evolution of a Paradigm and Literature Review from 1950-2009. Production Planning \& Control: The Management of Operations, 23, 641-662. https://doi.org/10.1080/09537287.2011.577460

[95] Moore, J.F. (1993) Predators and Prey: A New Ecology of Competition. Harvard Business Review, 71, 75-86.

[96] Opara-Martins, J., Sahandi, R. and Tian, F. (2016) Critical Analysis of Vendor Lockin and Its Impact on Cloud Computing Migration: A Business Perspective. Journal of Cloud Computing. Advances, Systems and Applications, 5, 1-18. https://doi.org/10.1186/s13677-016-0054-Z

[97] Cao, Y. and Gruca, T.S. (2005) Reducing Adverse Selection through Customer Relationship Management. Journal of Marketing, 69, 219-229. https://doi.org/10.1509/jmkg.2005.69.4.219

[98] Gustafsson, A., Johnson, M.D. and Roos, I. (2005) The Effects of Customer Satisfaction, Relationship Commitment Dimensions, and Triggers on Customer Retention. Journal of Marketing, 69, 210-218. https://doi.org/10.1509/jmkg.2005.69.4.210

[99] Rogers, E. (1962) The Diffusion of Innovations. The Free Press, New York.

[100] Brockhoff, K. (1967) A Test for the Product Life Cycle. Econometrica, 35, 472-484. https://doi.org/10.2307/1905649

[101] Cox, W.E. (1967) Product Life Cycles as Marketing Models. Journal of Business, 40, 375-384. https://doi.org/10.1086/295003

[102] Frederixon, M. (1969) An Investigation of the Product Life Cycle Concept and Its Application to New Product Proposal Evaluation within the Chemical Industry. Ph.D. Thesis, Michigan State University, East Lansing.

[103] Cunningham, M.T. (1969) The Application of Product Life Cycles to Corporate Strategy: Some Research Findings. European Journal of Marketing, 3, 32-44. https://doi.org/10.1108/EUM0000000005206

[104] Hinkle, J. (1966) Life Cycles. Nielsen, New York.

[105] Buzzell, R. (1966) Competitive Behavior and Product Life Cycles. In: Wright, J. and Goldstucker, J., Eds., New Ideas for Successful Marketing, American Marketing Association, Chicago, 46-67.

[106] Kotler, P. (1965) Phasing Out Weak Products. Harvard Business Review, 43, 107118.

[107] Rachmann, D.J. (1974) Marketing Strategy and Structure. Prentice Hall, Upper Saddle River.

[108] Dean, J. (1950) Pricing Policies for New Products. Harvard Business Review, 28, 45 53. 
[109] Bass, P. and Bass, F.M. (2001) Diffusion of Technology Generations: A Model of Adoption and Repeat Sales. Working Paper, University of Texas at Dallas, Dallas.

[110] Kamakura, W.A. and Ealasubramanian, S.K. (1987) Long-Term Forecasting with Innovation Diffusion Models: The Impact of Replacement Purchases. Journal of Forecasting, 6, 1-19. https://doi.org/10.1002/for.3980060102

[111] Olson, J. and Choi, S. (1985) A Product Diffusion Model Incorporating Repeat Purchases. Technological Forecasting and Social Change, 27, 385-397. https://doi.org/10.1016/0040-1625(85)90019-8

[112] Orbach, Y. and Fruchter, G.E. (2010) A Utility-Based Diffusion Model Applied to the Digital Camera Case. Review of Marketing Science, 8, 1-26. https://doi.org/10.2202/1546-5616.1105

[113] Cho, S.J. (2008) The Effectiveness of Parametric Approximation: A Case of Mainframe Computer Investment. Journal of Economic Research, 13, 125-148.

[114] Steffens, P.R. (2002) The Product Life Cycle Concept: Buried or Resurrected by the Diffusion Literature? Proceedings of the Academy of Management Conference, Denver, 23 September 2008, 1-29. https://doi.org/10.2139/ssrn.1264166

[115] Mahajan, V. and Muller, E. (1996) Timing, Diffusion, and Substitution of Successive Generations of Technological Innovations: The IBM Mainframe Case. Technological Forecasting and Social Change, 51, 109-132. https://doi.org/10.1016/0040-1625(95)00225-1

[116] Norton, J.A. and Bass, F.M. (1987) A Diffusion Theory Model of Adoption and Substitution for Successive Generations of High-Technology Products. Management Science, 33, 1069-1086. https://doi.org/10.1287/mnsc.33.9.1069

[117] Orbach, Y. and Fruchter, G.E. (2014) Predicting Product Life Cycle Patterns. Marketing Letters, 25, 37-52. https://doi.org/10.1007/s11002-013-9239-0

[118] Bass, F.M. (1969) A New Product Growth for Model Consumer Durables. Management Science, 15, 215-227. https://doi.org/10.1287/mnsc.15.5.215

[119] Katz, M. and Shapiro, C. (1986) Technology Adoption in the Presence of Network Externalities. Journal of Political Economy, 94, 822-841.

https://doi.org/10.1086/261409

[120] Loch, C.H. and Huberman, B.A. (1999) A Punctuated-Equilibrium Model of Technology Diffusion. Management Science, 45, 160-177. https://doi.org/10.1287/mnsc.45.2.160

[121] Mahajan, V., Muller, E. and Bass, F.M. (1993) New Product Diffusion Models. Handbooks in Operations Research and Management Science, 5, 349-408. https://doi.org/10.1016/S0927-0507(05)80031-3

[122] Schmidt, G.M. and Druehl, C.T. (2005) Changes in Product Attributes and Cost as Drivers of New Product Diffusion and Substitution. Production and Operations Management, 14, 272-285. https://doi.org/10.1111/j.1937-5956.2005.tb00024.x

[123] Srivastava, R.K., Mahajan, V., Ramaswami, S.N. and Cherian, J. (1985) A MultiAttribute Diffusion Model for Forecasting the Adoption of Investment Alternatives for Consumers. Technological Forecasting and Social Change, 28, 325-333. https://doi.org/10.1016/0040-1625(85)90034-4

[124] Van den Bulte, C. and Joshi, Y.V. (2007) New Product Diffusion with Influential and Imitators. Marketing Science, 26, 1-23. https://doi.org/10.1287/mksc.1060.0224

[125] Weerahandi, S. and Dalal, S.R. (1992) A Choice Based Approach to the Diffusion of a Service: Forecasting Fax Penetration by Market Segments. Marketing Science, 11, 39-53. https://doi.org/10.1287/mksc.11.1.39

[126] Mahajan, V., Sharma, S. and Wind, Y. (1983) An Approach to Repeat-Purchase Di- 
ffusion Analysis. Proceedings of the 1983 American Marketing Association Conference, $442-446$.

[127] Konczal, E.F. (1975) Models Are for Managers, Not Mathematicians. Journal of Systems Management, 26, 12-15.

[128] Wirtz, B.W., Pistoia, A., Ullrich, S. and Göttel, V. (2016) Business Models: Origin, Development and Future Research Perspectives. Long Range Planning, 49, 36-54. https://doi.org/10.1016/j.lrp.2015.04.001

[129] Al-Debei, M.M., El-Haddadeh, R. and Avison, D. (2008) Defining the Business Model in the New World of Digital Business. Proceedings of the Americas Conference on Information Systems, Toronto, 14-17 August 2008, 1-11.

[130] Casadesus-Masanell, R. and Ricart, J.E. (2010) From Strategy to Business Models and onto Tactics. Long Range Planning, 43, 195-215. https://doi.org/10.1016/j.lrp.2010.01.004

[131] Mansfield, G.M. and Fourie, L. (2004) Strategy and Business Models-Strange Bedfellows? A Case for Convergence and Its Evolution into Strategic Architecture. South African Journal of Business Management, 35, 35-44.

[132] Seddon, P.B., Geoffrey, P.L., Freeman, P. and Shanks, G. (2004) The Case for Viewing Business Models as Abstractions on Strategy. Communications of the Association for Information Systems, 13, 427-442.

[133] Demil, B. and Lecocq, X. (2010) Business Model Evolution: In Search of Dynamic Consistency. Long Range Planning, 43, 227-246. https://doi.org/10.1016/j.lrp.2010.02.004

[134] Johnson, M.W. (2010) Seizing the White Space: Business Model Innovation for Growth and Renewal. Harvard Business Press, Boston.

[135] Osterwalder, A. and Pigneur, Y. (2010) Business Model Generation: A Handbook for Visionaries, Game Changers, and Challengers. Wiley, New Jersey.

[136] Osterwalder, A., Pigneur, Y. and Tucci, C.L. (2005) Clarifying Business Models: Origins, Present, and Future of the Concept. Communications of the Association for Information Systems, 16, 1-25.

[137] Wirtz, B.W. (2000) Electronic Business. Gabler, Wiesbaden. https://doi.org/10.1007/978-3-322-92971-6

[138] Hamel, G. (2000) Leading the Revolution. Harvard Business School Press, Boston.

[139] Tikkanen, H., Lamberg, J.A., Parvinen, P. and Kallunki, J.H. (2005) Managerial Cognition, Action and the Business Model of the Firm. Management Decision, 43, 789-809. https://doi.org/10.1108/00251740510603565

[140] Voelpel, S.C., Leibold, M. and Tekie, E.B. (2004) The Wheel of Business Model Reinvention: How to Reshape Your Business Model to Leapfrog Competitors. Journal of Change Management, 4, 259-276. https://doi.org/10.1080/1469701042000212669

[141] Maass, W. and Varshney, U. (2008) Preface to the Focus Theme Section on "Smart Products". Electronic Markets, 18, 211-215. https://doi.org/10.1080/10196780802265645

[142] Bughin, J., Chui, M. and Manyika, J. (2010) Clouds, Big Data, and Smart Assets: Ten Tech-Enabled Business Trends to Watch. McKinsey Quarterly, 1-14.

[143] Dover, C. (2014) Worldwide SaaS Enterprise Applications 2014-2018 Forecast and 2013 Vendor Shares. IDC Research.

[144] Kumar, V. (2014) Making "Freemium" Work: Many Start-Ups Fail to Recognize the Challenges of this Popular Business Model. Harvard Business Review, 92, 27-29. 
[145] Lansiti, M. and Lakhani, K.R. (2014) Digital Ubiquity: How Connections, Sensors, and Data Are Revolutionizing Business. Harvard Business Review, 92, 90-99.

[146] Hui, G. (2014) How the Internet of Things Changes Business Models. Harvard Business Review, 92, 1-5.

[147] Statista (2016) Total Worldwide In-App Purchase Revenues from 2011 to 2017. http://www.statista.com/statistics/220186/total-global-in-app-revenue-forecast/

[148] Sensortower (2016) App Intelligence Overview for iOS-App Pokémon GO. https://sensortower.com/ios/us/niantic-inc/app/pokemon-go/1094591345/

[149] Barney, D. (2004) The Network Society. Polity Press, Blackwood.

[150] Solomon, M.R., Marshall, G.W., Stuart, E.W., Mitchell, V. and Barnes, B. (2009) Marketing: Real People, Real Decisions. Pearson, Harlow.

[151] Tiwana, A., Konsynski, B. and Bush, A.A. (2010) Platform Evolution: Coevolution of Platform Architecture, Governance, and Environmental Dynamics. Information Systems Research, 21, 675-687. https://doi.org/10.1287/isre.1100.0323

[152] Yoo, Y., Henfridsson, O. and Lyytinen, K. (2010) The New Organizing Logic of Digital Innovation: An Agenda for Information Systems Research. Information Systems Research, 21, 724-735. https://doi.org/10.1287/isre.1100.0322

[153] Ehret, M. and Wirtz, J. (2017) Unlocking Value from Machines: Business Models and the Industrial Internet of Things. Journal of Marketing Management, 33, 111130. https://doi.org/10.1080/0267257X.2016.1248041

Submit or recommend next manuscript to SCIRP and we will provide best service for you:

Accepting pre-submission inquiries through Email, Facebook, LinkedIn, Twitter, etc. A wide selection of journals (inclusive of 9 subjects, more than 200 journals)

Providing 24-hour high-quality service

User-friendly online submission system

Fair and swift peer-review system

Efficient typesetting and proofreading procedure

Display of the result of downloads and visits, as well as the number of cited articles

Maximum dissemination of your research work

Submit your manuscript at: http://papersubmission.scirp.org/

Or contact ait@scirp.org 